\title{
KEBENARAN FORMAL DALAM PEMBUKTIAN DI PENGADILAN AGAMA
}

\author{
Tamat Zaifudin \\ Program Studi Doktor Ilmu Hukum \\ Pascasarjana Universitas Islam Bandung \\ e-mail: tamatz01@gmail.com
}

\begin{abstract}
Abstrak- Penyelesaian sengketa sipil yang bertumpu pada kebenaran formal belum sepenuhnya memberikan perlindungan dan jaminan untuk mencapai keadilan. Ini akan membuat fungsi lembaga peradilan menjadi tidak signifikan. Penelitian ini bertujuan untuk mengetahui urgensi penerapan kebenaran formal sebagai alat bukti di pengadilan agama, yang karakternya berbeda dari pengadilan lain. Hasil penelitian ini menunjukkan bahwa pengadilan agama memiliki karakter yang berbeda dari pengadilan lainnya terutama dalam prioritas menggunakan kebenaran materi sebagai alat bukti.
\end{abstract}

\section{Kata kunci: Kebenaran Formal, Kebenaran Material, Pengadilan Agama.}

Abstract- Civil dispute settlement which rests on the formal truth has not yet fully provided protection and guarantee for achieving justice. This would make the function of judicial institution being insignificant. This research aims to find out the urgency of the formal truth application as a tool of evidence at religious court, whose distinguish character differ from other courts. The result of this research indicates that religious court has distinguish character differ from other court especially in the priority of using material truth as a tool of evidence.

\section{Keywords: Formal Truth, Material Truth, Religious Court.}

\section{A. PENDAHULUAN}

Kedudukan peradilan dalam negara hukum dan masyarakat demokrasi, masih tetap diandalkan sebagai "katup penekan" (palpe value) atas segala pelanggaran hukum, ketertiban masyarakat dan pelanggaran ketertiban umum. Peradilan masih tetap diharapkan sebagai "the last resort", yakni sebagai tempat terakhir mencari kebenaran dan keadilan. Pengadilan masih diandalkan sebagai badan yang berfungsi menegakkan kebenaran dan keadilan (to enforce the truth and to enforce justice) (Yahya Harahap, 1997:237).

$$
\text { Pengajuan perkara ke }
$$

pengadilan, bertujuan untuk mendapatkan pemecahan dan penyelesaian perkara secara adil sesuai dengan harapan dan keinginan para pencari keadilan (justiciabellen). Suatu perkara supaya dapat diputus secara adil harus diketahui duduk perkaranya secara jelas, yaitu mana 
peristiwa yang benar dan mana peristiwa yang salah.

Untuk menentukan mana peristiwa yang benar dan mana peristiwa yang salah dapat dilakukan melalui proses pembuktian di persidangan. Pihak-pihak yang berperkara dalam persidangan harus mengemukakan peristiwa-peristiwa yang dapat dijadikan dasar untuk meneguhkan haknya, maupun untuk membantah hak pihak lain. Peristiwaperistiwa yang dikemukakan oleh para pihak tentu saja tidak cukup sekedar disampaikan begitu saja secara lisan maupun tertulis, tetapi harus disertai dan didukung dengan bukti-bukti yang sah menurut hukum agar dapat dipastikan kebenarannya. Dengan kata lain peristiwa-peristiwa itu harus disertai pembuktian secara yuridis (Riduan Syahrani, 1988:55). Tujuan dari pembuktian secara yuridis adalah untuk mencari atau menemukan kebenaran peristiwa yang digunakan sebagai dasar putusan hakim, yang mempunyai akibat hukum (Sudikno Mertokusumo, 1984:86).

Dalam membuktikan secara yuridis, yakni untuk mencari kebenaran dalam suatu peristiwa tidaklah sama. Kebenaran yang hendak dicari hakim dalam menyelesaikan suatu perkara, dapat berupa kebenaran formal (formele waarheid) maupun kebenaran materiil (materiele waarheid) yang keduanya termasuk dalam lingkup kebenaran hukum yang bersifat kemasyarakatan (maatschappelijke werkelijkheid).

Dalam pembuktian perkara perdata, yang hendak dicari hakim adalah kebenaran formal, yang berarti hakim terikat kepada keterangan atau alat-alat bukti yang disampaikan oleh para pihak. Di sini hakim cukup dengan pembuktian yang tidak meyakinkan

(Sudikno

Mertokusumo, 1984:87). Hal ini sejalan dengan yurisprudensi Mahkamah Agung tanggal 3 Agustus 1974, yang membenarkan pertimbangan Pengadilan Tinggi, bahwa dalam hukum acara perdata tidak perlu adanya keyakinan hakim (Mahkamah Agung RI, 1977:210). Sedangkan pencarian kebenaran materiil terutama dilakukan hakim dalam menyelesaikan perkara-perkara pidana dan administratif. 
Istilah kebenaran formal dalam perkara perdata memang tidak secara eksplisit disebutkan dalam ketentuan peraturan perundang-undangan hukum acara perdata yang berlaku, seperti HIR dan Rbg, akan tetapi adanya kebenaran formal tersebut disimpulkan dari beberapa pasal dalam HIR maupun Rbg, antara lain pasal-pasal yang mengatur hukum pembuktian (Pasal 162 sampai denga Pasal 177 HIR/Pasal 282 sampai dengan Pasal 314 Rbg) dan Pasal 178 HIR/Pasal 315 Rbg. tentang kewajiban dan larangan hakim.

Dengan adanya ketentuanketentuan dalam HIR maupun dalam Rbg tersebut, maka para ahli hukum, seperti HM. Sudikno Mertokusumo, Retnowulan Sutantio dan Iskandar Oeripkartawinata serta Supomo (Supomo, 1993:13), umumnya sependapat bahwa dalam perkara perdata, kebenaran yang hendak dicari hakim dalam pembuktian adalah kebenaran formal.

Menemukan kebenaran formal dalam penyelesaian perkara perdata dapat terlihat jelas antara lain dalam hal penggunaan alat bukti pengakuan. Pengakuan di muka persidangan menurut Pasal 174 HIR/311 Rbg. merupakan bukti yang sempurna terhadap siapa yang melakukannya, baik sendiri maupun dengan perwakilan orang lain yang telah mendapat kuasa khusus untuk itu. Dengan demikian apabila tergugat memberikan pengakuan di depan sidang pengadilan terhadap isi gugatan penggugat, maka penggugat tidak perlu lagi mengadakan pembuktian terhadap hal-hal yang telah diakui tergugat, walaupun pengakuan tersebut diberikan agar perkara yang diajukan cepat terselesaikan dan pengakuan tersebut dilakukan secara terpaksa.

Dengan adanya pengakuan tergugat tersebut sudah cukup untuk membuktikan peristiwa atau hubungan hukum yang menimbulkan hak baginya dan perselisihan para pihak dianggap selesai, sekalipun mungkin pengakuan tergugat tidak benar, namun hakim tidak perlu meneliti lebih lanjut kebenaran pengakuan tersebut. Padahal dalam praktik, pengakuan tergugat di muka persidangan, belum tentu menggambarkan keadaan yang sebenarnya. 
Dalam membuktikan perkara dijual kepada pihak tergugat perdata, hakim juga menemui (Subekti, 1989:9). Hal itu dapat berbagai pembatasan (Subekti, terjadi karena berdasarkan Pasal 165 1989:8). Misalnya apabila pihak HIR/Pasal 285 Rbg bahwa akta penggugat memerintahkan kepada otentik merupakan alat bukti yang pihak tergugat supaya ia bersumpah bahwa ia benar-benar sudah mengikat dan sempurna. Mengikat membayar hutangnya kepada penggugat dengan menerimakan uang sejumlah itu kepada penggugat sendiri dan tergugat berani mengangkat sumpah tersebut, maka hakim harus menganggap bahwa benar tergugat itu sudah membayar hutangnya dan wajiblah hakim menolak gugatan penggugat.

Mencari kebenaran formal dalam perkara perdata juga dapat tercermin ketika hakim melakukan penilaian terhadap alat bukti yang berupa akta otentik. Apabila seorang tergugat dalam sidang pengadilan menunjukkan sebuah akta notaris yang isinya menerangkan bahwa pada suatu hari penggugat sudah menghadap di muka notaris dan pada waktu itu penggugat telah menerangkan menjual rumahnya kepada tergugat, maka hakim perdata harus menganggap bahwa rumah tersebut sungguh-sungguh sudah dalam arti bahwa apa yang dicantumkan dalam akta tersebut harus dipercaya oleh hakim, yaitu harus dianggap sebagai sesuatu yang benar, selama ketidakbenarannya tidak terbukti. Sempurna dalam arti bahwa dengan akta otentik tersebut sudah cukup untuk membuktikan suatu peristiwa atau hak tanpa perlu penambahan pembuktian dengan alatalat bukti lain. Padahal apabila ditelusuri belum tentu alat bukti akta notaris tersebut diperoleh melalui cara-cara dan prosedur yang semestinya, misalnya karena hal-hal yang dicantumkan dalam akta tersebut tidak sepenuhnya benar atau berbeda dengan peristiwa sesungguhnya. Dengan demikian meskipun secara lahiriah, akta tersebut dibuat resmi oleh pejabat yang berwenang, namun apabila diteliti secara mendalam ternyata akta notaris tersebut mengandung cacat yuridis. 
Penyelesaian perkara perdata tentunya menjadi tidak signifikan yang lebih menekankan pada lagi.

pencarian kebenaran formal, Pada gilirannya akan berakibat terkadang menjadi alasan mengurangi kepercayaan masyarakat ketidakpuasan pihak-pihak yang terhadap kinerja dan integritas berperkara atas putusan hakim. institusi peradilan. Sehingga dalam Apabila hakim semata-mata hanya praktik di pengadilan agama yang mencari kebenaran formal, sangat mempunyai ciri dan karakter yang mungkin terjadi pihak yang berbeda dengan pengadilan lainnya, sesungguhnya benar dapat dikalahkan apakah memungkinkan dalam perkaranya, karena tidak dapat membuktikan suatu perkara berusaha menunjukkan bukti-bukti yang menemukan kebenaran materiil atau diminta di muka persidangan, kebenaran yang sebenarnya, karena sehingga putusan hakim dalam praktik tidak selalu mencerminkan keadaan yang sebenarnya. Akibat dari itu semua, para pencari keadilan merasa adanya ketidakadilan dan dirugikan hak-hak dan kepentingannya. pencarian kebenaran formal semata dirasakan belum cukup memenuhi rasa keadilan.

Dari latar belakang sebagaimana terurai di atas, maka masalah utama yang hendak diteliti dan dikaji dalam tulisan ini adalah

Oleh karena itu, upaya penyelesaian perkara perdata yang berpijak pada kebenaran formal belum dapat sepenuhnya memberikan perlindungan dan jaminan terciptanya keadilan bagi para pencari keadilan. Apabila hal itu terus dipertahankan, maka nampaknya semboyan bahwa lembaga peradilan sebagai benteng terakhir bagi pencari keadilan dalam mencari kebenaran dan keadilan bagaimana penerapan kebenaran formal dalam pembuktian di Pengadilan Agama yang mempunyai ciri dan karakter berbeda dengan pengadilan lainnya.

\section{B. HASIL DAN PEMBAHASAN}

Pasal 54 Undang-Undang Nomor 7 Tahun 1989, sebagaimana telah diubah dengan Undang-Undang Nomor 3 Tahun 2009 dan perubahan 
kedua dengan Undang-Undang Nomor 50 Tahun 2009 menyebutkan:

"Hukum acara yang berlaku pada pengadilan dalam lingkungan Peradilan Agama adalah Hukum Acara Perdata yang berlaku pada pengadilan dalam lingkungan Peradilan Umum, kecuali yang telah diatur secara khusus dalam undang-undang ini”.

Hal yang diatur secara khusus dalam undang-undang ini antara lain tentang pembebanan biaya perkara yang harus dibayar oleh penggugat/pemohon, pembuktian dengan alasan syiqaq, penyelesaian gugatan perceraian yang didasarkan atas alasan zina (li'an) dan beberapa ketentuan lain yang diatur secara khusus.

Oleh karena hukum acara yang berlaku di pengadilan dalam lingkungan Peradilan Agama sama dengan hukum acara perdata yang berlaku di pengadilan dalam lingkungan Peradilan Umum, kecuali terhadap hal-hal yang telah diatur secara khusus dalam Undang-Undang Nomor 7 Tahun 1989, maka hukum acara perdata yang berlaku di lingkungan peradilan umum diberlakukan juga untuk lingkungan peradilan agama.

Mengajukan perkara ke pengadilan, bertujuan untuk mendapatkan pemecahan dan penyelesaian perkaranya secara baik sesuai dengan harapan dan keinginan para pencari keadilan (justiciabellen), yaitu untuk mendapatkan, keadilan, kepastian hukum dan kemanfaatan. Suatu perkara supaya dapat diputus secara baik harus diketahui duduk perkaranya secara jelas, yaitu mana peristiwa yang benar dan mana peristiwa yang salah.

Pembuktian diperlukan dalam mengadili suatu sengketa di muka pengadilan (juridicto contentiosa) maupun dalam perkara-perkara permohonan yang menghasilkan suatu penetapan (juridicto voluntair). Dalam suatu proses perdata, salah satu tugas hakim adalah untuk menyelidiki apakah suatu hubungan hukum yang menjadi dasar gugatan benar-benar ada atau tidak. Adanya hubungan hukum inilah yang harus terbukti apabila penggugat menginginkan kemenangan dalam suatu perkara. Apabila penggugat tidak berhasil untuk membuktikan 
dalil-dalil yang menjadi dasar gugatannya, maka gugatannya tersebut akan ditolak, namun apabila sebaliknya maka gugatannya tersebut akan dikabulkan.

Pasal 163 HIR/Pasal 283 RBg menyatakan:

"Barangsiapa mengatakan mempunyai suatu hak atau mengemukakan suatu perbuatan untuk meneguhkan haknya itu, atau untuk membantah hak orang lain, haruslah membuktikan adanya perbuatan itu".

Membuktikan secara yuridis, yakni untuk mencari kebenaran dalam suatu peristiwa tidaklah sama. Kebenaran yang hendak dicari hakim dalam menyelesaikan suatu perkara, dapat berupa kebenaran formal (formele waarheid) maupun kebenaran materiil (materiele waarheid) yang keduanya termasuk dalam lingkup kebenaran hukum yang bersifat kemasyarakatan (maatschappelijke werkelijkheid).

Para ahli hukum, seperti Sudikno Mertokusumo, Retnowulan Sutantio, Iskandar Oeripkartawinata dan Supomo, mereka sependapat bahwa dalam perkara perdata, kebenaran yang hendak dicari adalah kebenaran formal, yang berarti hakim terikat kepada keterangan atau alatalat bukti yang disampaikan oleh para pihak (Sudikno Mertokusumo, 1984:86).

Istilah kebenaran formal dalam perkara perdata memang tidak secara eksplisit disebutkan dalam ketentuan peraturan perundang-undangan hukum acara perdata yang berlaku, sebagaimana dalam HIR dan Rbg., akan tetapi adanya kebenaran formal dapat disimpulkan dari beberapa pasal dalam HIR maupun Rbg tersebut, antara lain pasal-pasal yang mengatur hukum pembuktian (Pasal 162 s/d Pasal 177 HIR/Pasal 282 s/d Pasal 314 Rbg) dan Pasal 178 HIR/Pasal 315 Rbg. tentang kewajiban dan larangan hakim.

Menemukan kebenaran formal dalam penyelesaian perkara perdata dapat terlihat jelas antara lain dalam hal penggunaan alat bukti pengakuan. Pengakuan di muka persidangan menurut Pasal 311 Rbg./174 HIR:

"Pengakuan yang diucapkan di hadapan hakim, cukup menjadi bukti untuk memberatkan orang yang mengaku itu, baik yang diucapkannya sendiri, maupun dengan pertolongan orang lain, 
yang istimewa dikuasakan untuk itu".

Dari ketentuan tersebut dapat difahami, bahwa alat bukti pengakuan merupakan bukti yang sempurna terhadap siapa yang melakukannya, baik sendiri maupun dengan perwakilan/dikuasakan kepada orang lain yang telah mendapat kuasa khusus untuk itu. Dengan demikian apabila tergugat memberikan pengakuan di depan sidang pengadilan terhadap isi gugatan penggugat, maka penggugat tidak perlu lagi mengadakan pembuktian terhadap hal-hal yang telah diakui tergugat, walaupun pengakuan tersebut diberikan agar perkara yang diajukan cepat terselesaikan dan pengakuan tersebut dilakukan secara terpaksa.

Dengan adanya pengakuan tergugat tersebut sudah cukup untuk membuktikan peristiwa atau hubungan hukum yang menimbulkan hak baginya. Dengan adanya pengakuan tergugat tersebut, maka perselisihan para pihak dianggap selesai, sekalipun mungkin pengakuan tergugat tidak benar, namun hakim tidak perlu meneliti lebih lanjut kebenaran pengakuan tersebut. Padahal dalam praktik, pengakuan tergugat di muka persidangan, belum tentu menggambarkan keadaan yang sebenarnya.

Dalam membuktikan suatu peristiwa, hakim perdata menemui berbagai pembatasan. Misalnya apabila pihak penggugat memerintahkan kepada pihak tergugat supaya ia bersumpah bahwa ia benarbenar sudah membayar nafkah madliyah kepada penggugat dengan memberikan uang sejumlah itu kepada penggugat sendiri dan tergugat berani mengangkat sumpah tersebut, maka hakim harus menganggap bahwa benar tergugat itu sudah membayar nafkah madliyah dan wajiblah hakim menolak gugatan penggugat.

Mencari kebenaran formal dalam perkara perdata juga dapat tercermin ketika hakim melakukan penilaian terhadap alat bukti yang berupa akta otentik. Apabila seorang tergugat dalam sidang pengadilan menunjukkan sebuah akta notaris yang isinya menerangkan bahwa pada suatu hari penggugat sudah 
menghadap di muka notaris dan pada waktu itu penggugat telah menerangkan menjual rumahnya kepada tergugat, maka hakim perdata harus menganggap bahwa rumah tersebut sungguh-sungguh sudah dijual kepada pihak tergugat. Hal itu dapat terjadi karena berdasarkan (Pasal 165 HIR/285 Rbg).

Dari ketentuan tersebut dapat difahami, bahwa akta otentik merupakan alat bukti yang mengikat dan sempurna. Mengikat dalam arti bahwa apa yang dicantumkan dalam akta tersebut harus dipercaya oleh hakim, yaitu harus dianggap sebagai sesuatu yang benar, selama ketidakbenarannya tidak terbukti. Sempurna dalam arti bahwa dengan akta otentik tersebut sudah cukup untuk membuktikan suatu peristiwa atau hak tanpa perlu penambahan pembuktian dengan alat-alat bukti lain. Padahal apabila ditelusuri belum tentu alat bukti akta notaris tersebut diperoleh melalui cara-cara dan prosedur yang semestinya, misalnya karena hal-hal yang dicantumkan dalam akta tersebut tidak sepenuhnya benar atau berbeda dengan peristiwa sesungguhnya. Dengan demikian meskipun secara lahiriah, akta tersebut dibuat resmi oleh pejabat yang berwenang, namun kalau diteliti secara mendalam ternyata akta notaris tersebut mengandung cacat yuridis.

Penyelesaian perkara perdata yang lebih menekankan pada pencarian kebenaran formal, belum menjamin tercapainya keadilan, kepastian hukum dan kemanfaatan, karena terkadang menjadi alasan ketidakpuasan pihak-pihak yang berperkara atas putusan hakim. Apabila hakim semata-mata hanya mencari kebenaran formal, sangat mungkin terjadi pihak yang sesungguhnya benar dapat dikalahkan perkaranya, karena tidak dapat menunjukkan bukti-bukti yang diminta di muka persidangan, sehingga putusan hakim dalam praktik tidak selalu mencerminkan keadaan yang sebenarnya. Akibat dari itu semua, para pencari keadilan merasa adanya ketidak adilan dan dirugikan hak-hak dan kepentingannya.

Oleh karena itu, upaya penyelesaian perkara perdata yang berpijak pada kebenaran formal belum dapat sepenuhnya memberikan 
perlindungan dan jaminan terciptanya keadilan, kepastian hukum dan kemanfaatan bagi para pencari keadilan. Apabila hal itu terus dipertahankan, maka nampaknya semboyan bahwa lembaga peradilan sebagai benteng terakhir bagi pencari keadilan dalam mencari keadilan, kepastian dan kemanfaatan tentunya menjadi tidak signifikan lagi. Pada gilirannya akan berakibat mengurangai kepercayaan masyarakat terhadap kinerja dan integritas institusi peradilan,sehingga dalam praktik peradilan perdata, (pengadilan agama) perlu menuju kepada kebenaran materiil atau kebenaran yang sebenarnya.

Dalam perkara perceraian misalnya, sebagaimana diatur dalam Pasal 22 ayat (2) Undang-Undang Nomor 1 Tahun 1974 tentang Perkawinan menyatakan:

"Gugatan tersebut dalam ayat (1) dapat diterima apabila telah cukup jelas bagi pengadilan mengenai sebabsebab perselisihan dan pertengkaran itu dan setelah mendengar pihak keluarga serta orang-orang yang dekat dengan suami-isteri itu".
Ketentuan tersebut mengatur tentang tata cara perceraian karena alasan antara suami dan isteri terusmenerus terjadi perselisihan dan pertengkaran dan tidak ada harapan akan hidup rukun lagi dalam rumah tangga, dimana perkara tersebut dapat diterima apabila telah terpenuhi 3 (tiga) syarat, yaitu:

1. Apabila telah cukup jelas bagi pengadilan mengenai sebab-sebab perselisihan dan pertengkaran itu;

2. Setelah mendengar pihak keluarga;

3. Setelah mendengar orang-orang yang dekat dengan suami-isteri itu.

Ketiga syarat tersebut merupakan syarat yang bersifat limitatif, yaitu harus ada ketigatiganya secara bersamaan dalam setiap perkara. Dengan adanya ketiga syarat tersebut, maka ketentuan Pasal 174 HIR/Pasal $311 \mathrm{Rbg}$, tentang alat bukti pengakuan dan Pasal 165 HIR/Pasal $285 \mathrm{Rbg}$, tentang alat bukti akta otentik, tidak lagi mengikat hakim, karena walaupun sudah ada pengakuan dan sudah ada akta otentik yang membuktikan peristiwa tersebut, namun apabila dalam perkara tersebut belum mendengar keterangan pihak keluarga dan belum mendengar 
keterangan orang-orang yang dekat dengan suami isteri tersebut, maka pemeriksaan perkara tersebut tidak dianggap sah atau dianggap belum pernah diperiksa dengan baik di pengadilan. Dengan demikian jelas bahwa bukan lagi kebenaran formal yang dicari.

Begitu juga dalam perkara yang berkaitan dengan masalah pembuktian harta, walaupun sudah ada akta otentik berupa sertifikat tanah, tetapi masih diperlukan keterangan saksi-saksi serta diperintahkan untuk melaksanakan sidang pemeriksaan setempat sesuai dengan Surat Edaran Mahkamah Agung Nomor 7 Tahun 2001.

Dalam Islam disebutkan, bahwa hakim diwajibkan untuk mencapai suatu kebenaran yang sebenarnya (kebenaran materiil). Hal ini karena Islam adalah suatu agama yang datang dari Allah SWT yang Maha Adil, Maha Besar, dan Maha Bijaksana dalam segala hal terutama dalam masalah-masalah hukum. Pendapat ini berdasarkan Al-Qur'an Surat An-Nahl (16) ayat 90, Surat Al-Hujurat (49) ayat 9, Surat At-Tien ayat (95) ayat 8 dan Surat An-Nisa'

(4) ayat 135 yang artinya:

"Hai orang-orang yang beriman! Hendaklah kamu benar-benar menjadi orang yang menegakkan keadilan dan menjadi saksi utuk Allah, walaupun atas dirimu atau ibu bapakmu dan kaum kerabatmu" (Q.S. An-Nisa' (4) ayat 135).

Apabila diperhatikan ayat-ayat di atas jelas dan tegas memerintahkan agar setiap manusia benar-benar berlaku adil, dengan arti kata yang sebenar-benarnya, yakni diwajibkan berlaku adil di dalam segala masalah, termasuk di dalamnya dalam mengadili perkara. Oleh karena itu seorang hakim dalam mengadili sesuatu perkara, baik perkara perdata ataupun perkara pidana harus mengetahui dengan yakin mana yang harus dimenangkan dan mana yang harus dikalahkan sesuai dengan hal yang sebenarnya.

Rasulullah SAW telah mengkualifisir hakim-hakim yang masuk surga dan yang bakal dimasukkan ke dalam neraka. Hakimhakim itu tidak akan selamat dari neraka selain mereka yang mengetahui akan kebenaran sesuatu perkara kemudian memberikan 
keputusan terhadap perkara itu berdasarkan keyakinan dan kebenarannya sesuai dengan ketentuan Tuhan. Sebagaimana sabda Rasulullah SAW:

"Rasulullah SAW bersabda: Hakim itu terbagi ke dalam tiga golongan. Golongan pertama akan dimasukkan ke dalam surga, sedang dua golongan lagi akan dimasukkan ke dalam neraka. Hakim yang dimasukkan ke dalam surga adalah hakim yang mengetahui akan kebenaran dan menjatuhkan putusannya berdasarkan keadilan dan kebenarannya itu. Bagi hakim yang mengerti kebenaran, tetapi menyimpang dari kebenaran itu dan memutus secara dzalim, maka ia akan dimasukkan ke dalam neraka. Begitu juga bagi hakim yang menjatuhkan putusan berdasarkan kejahilannya (kebodohan), maka ia akan dimasukkan kedalam neraka" (H.R. Abu Dawud).

Dari hadits di atas dapat difahami, bahwa hanya satu hakim yang selamat dan masuk surga yaitu, hakim yang mengetahui kebenaran dan menghukum dengannya. Kebenaran yang dimaksud disini adalah kebenaran dengan arti yang sebenar-benarnya (materiil waarheid), dengan kata lain kebenaran menurut lahir dan batin, bukan yang ada pada lahirnya saja, apalagi kebenaran semu. Berkenaan dengan itu Allah SWT berfirman dalam surat Al-Isra (17) ayat 36:

"Dan janganlah kamu mengikut apa yang tidak kamu ketahui, karena sesungguhnya pendengaran dan penglihatan dan hati semuanya itu akan ditanya." (QS. Al-Isra'(17):36).

Ayat di atas memperingatkan kepada seluruh kaum muslimin, termasuk di dalamnya hakim agar tidak sembarangan dalam memutus suatu perkara, hendaklah hakim memperhatikan betul tindakannya karena semuanya akan dimintai pertanggungjawabannya nanti, disamping ditangan hakim terletak nasib orang-orang yang meminta dan mencari keadilan. Memang untuk mencapai kebenaran yang hakiki atau kebenaran sejati sungguh sangat sulit sekali. Oleh karena itu Nabi SAW melarang hakim mengadili di waktu ia marah, dan melarang anak menjadi saksi terhadap ayahnya. Hal ini dimaksudkan agar hakim dalam memutuskan suatu perkara dapat mencapai kebenaran yang sebenarnya, sebab dikhawatirkan 
bila hakim mengadili dibarengi dengan adanya rasa marah, benci atau rasa cinta yang sangat seperti cinta ayah kepada anaknya dan sebaliknya, maka tidak akan tercapai putusan yang objektif dan adil. Sedangkan Allah SWT menyuruh agar hakim menyampaikan amanah kepada yang berhak menerimanya (QS. AnNisa'(4) ayat : 58).

Secara logis dapat dipahami bahwa tidak mungkin hakim dapat menyampaikan amanat/memutus perkara kepada yang berhak, tanpa kebenaran sejati, yakni kebenaran menurut lahir dan batin (kebenaran materil). Dalam hal ini Ibnu Rusyd berkata dalam kitabnya Bidayatul Mujtahid (Ibn Rusyd, 1990 : 470).

"Bahwa para ulama sepakat berpendapat, seorang qadli menghukum dengan ilmunya (keyakinannya) di dalam menerima dan menolak buktibukti. Bila ada beberapa orang saksi memberikan keterangan yang bertentangan dengan pengetahuan (keyakinan) hakim, maka hakim tidak boleh menghukum dengan dasar bukti tersebut".

Dari keterangan Ibnu Rusyd di atas jelaslah bahwa di dalam sistem peradilan Islam, maka pedoman hakim dalam menjatuhkan putusan adalah adanya bukti yang sah dan meyakinkan hakim akan kebenarannya. Senada dengan itu Abdoerraoef mengatakan bahwa hukum Al-Quran menuntut adanya keyakinan hakim dalam perkara perdata. Dengan demikian nyatalah bahwa dalam hukum Islam, baik dalam perkara perdata mauupun dalam perkara pidana menuntut hakim memutuskan perkara berdasarkan kebenaran materiil. Hal ini sesuai dengan tujuan dari hukum Islam itu yaitu untuk mencari kemaslahatan dan keadilan yang sebenarnya.

Sebagaimana telah disebutkan di atas, bahwa peradilan agama adalah salah satu pelaku kekuasaan kehakiman bagi rakyat pencari keadilan yang beragama Islam mengenai perkara tertentu sebagaimana dimaksud dalam undang-undang. Dari ketentuan tersebut dapat difahami, bahwa pengadilan agama adalah pengadilan khusus, yang kekhususannya meliputi 2 (dua hal pokok, yaitu :

1. Kekhususan dalam subyek hukum, yaitu pengadilan agama adalah 
pelaku kekuasaan kehakiman bagi rakyat pencari keadilan yang beragama Islam dan bagi orangorang yang menundukkan diri kepada hukum Islam;

2. Kekhususan dalam obyek hukum, yaitu pengadilan agama adalah pelaku kekuasaan kehakiman dalam perkara-perkara tertentu yang merupakan sebagian dari syari'at Islam;

Tujuan disyari'atkannya hukum Islam (maqâshid as-syarî’ah) adalah untuk kemaslahatan manusia di dunia dan di akhirat, lahir dan batin. Konsep maslahat dalam ruang lingkup tujuan disyari'atkannya hukum Islam, memiliki tiga tingkatan/klasifikasi, yaitu :

1. Tingkatan primer (al-dladuriy), adalah kemaslahatan yang berhubungan dengan kebutuhan pokok umat manusia di dunia dan di akhirat, dalam arti tanpa kehadirannya (eksistensi maslahat ini) akan menimbulkan kerusakan di dunia dan di akhirat. Kategori dharûriyah meliputi lima hal, yang disebut al-dlaruriyat al-khams, yaitu lima tujuan utama hukum Islam, yaitu memelihara agama, memelihara jiwa, memelihara akal, memelihara keturunan atau kehormatan dan memelihara harta.Tujuan hukum mu'amalat merujuk kepada pemeliharaan jiwa, akal, harta dan keturunan. Tujuan hukum pidana (jinayah) yang meliputi amar ma'ruf nahi munkar merujuk kembali kepada pemeliharaan keseluruhan tujuan hukum yang bersifat primer.

2. Tingkatan sekunder (al-Tahajji), yaitu kemaslahatan yang dibutuhkan dalam menyempurnakan kemaslahatan primer sebelumnya yang berbentuk keringanan untuk mempertahankan dan memelihara kebutuhan mendasar manusia, serta memberikan keleluasaan kepadanya untuk memperluas tujuan. Apabila kemaslahatan tingkat sekunder ini tidak dicapai, maka manusia akan mengalami kesulitan dalam memelihara agama, jiwa, akal, keturunan, dan harta mereka.

3. Tingkatan tertier (al-Tahsiniyah), yaitu memelihara kelima unsur pokok dalam tingkatan alDharuriyah dengan cara meraih 
dan menetapkan hal yang pantas dan layak dari kebiasaan-kebiasaan hidup yang baik serta menghindarkan sesuatu yang dipandang sebaliknya oleh akal sehat. Hal ini tercakup dalam pengertian akhlak yang mulia (akhlaqul karimah). Jika kemaslahatan tersier tidak tercapai, maka manusia tidak sampai mengalami kesulitan dalam memelihara kelima unsur pokoknya, akan tetapi mereka dipandang menyalahi nilai-nilai kepatutan dan tidak mencapai taraf hidup bermartabat.

Perkara-perkara yang menjadi kewenangan pengadilan agama adalah perkara-perkara yang terkait erat dengan kebutuhan primer (dlaruriyah) manusia, yang harus ada demi adanya kehidupan manusia. Apabila tujuan itu tidak tercapai, maka akan menimbulkan ketidakstabilan kemaslahatan hidup manusia di dunia dan di akhirat, lahir dan batin, bahkan merusak kehidupan itu sendiri.

Dalam rangka mencari kebenaran materiil, perlu diperhatikan beberapa prinsip sebagai pegangan bagi hakim maupun bagi para pihak yang berperkara. Tugas dan peran hakim hanya terbatas menerima dan memeriksa sepanjang mengenai halhal yang diajukan penggugat dan tergugat. Oleh karenai tu, fungsi dan peran hakim dalam proses perkara perdata hanya terbatas pada mencari dan menemukan kebenaran sebatas yang terungkap dalam persidangan, dimana kebenaran tersebut diwujudkan sesuai dengan dasar alasan dan fakta-fakta yang diajukan oleh para pihak selama proses persidangan berlangsung. Sehubungan dengan sifat pasif tersebut, apabila hakim yakin bahwa apa yang digugat dan diminta penggugat adalah benar, tetapi penggugat tidak mampu mengajukan bukti tentang kebenaran yang diyakininya, maka hakim harus menyingkirkan keyakinan itu dengan menolak kebenaran dalil gugatan, karena tidak didukung dengan bukti dalam persidangan. Makna pasif bukan hanya sekedar menerima dan memeriksa apa-apa yang diajukan para pihak, tetapi tetap berperan dan berwenang menilai kebenaran fakta yang diajukan ke persidangan. 
Dalam mencari dan menemukan kebenaran, hakim terikat dengan keterangan dan bukti-bukti formal yang terungkap dalam persidangan. Hal ini sejalan dengan asas hukum acara perdata yang menyatakan bahwa hakim bersikap pasif, yaitu hakim tidak menentukan ruang lingkup atau luas pokok sengketa yang diajukan kepadanya, tetapi yang menentukan adalah pihak-pihak yang berperkara sendiri. Dalam hal ini hakim dilarang memutuskan hal-hal yang tidak dituntut atau mengabulkan lebih daripada yang dituntut (Pasal 178 ayat (3) HIR). Hakim hanya sekedar menerima, meninjau dan menilai bahan-bahan yang disampaikan oleh pihak-pihak yang berperkara dan kemudian mengambil keputusan atas dasar penilaian terhadap bahan-bahan yang diajukan tersebut.

Dalam membuktikan suatu perkara, hakim dituntut mencari kebenaran materiil atau kebenaran yang sebenarnya terhadap perkara yang sedang diperiksanya, karena tujuan pembuktian itu adalah untuk meyakinkan hakim atau memberikan kepastian kepada hakim tentang adanya peristiwa-peristiwa tertentu, sehingga hakim dalam mengkonstatir, mengualifisir dan mengkonstituir, serta mengambil keputusan berdasarkan kepada pembuktian tersebut.

Dengan demikian sistem pembuktian, tidak lagi berdasarkan kepada kebenaran formal saja tetapi juga pada kebenaran materiil, artinya walaupun alat bukti telah mencukupi menurut formal dengan alat bukti yang ditentukan dalam undangundang, namun hakim tidak boleh memutus perkara apabila ia tidak yakin bahwa hal itu telah terbukti secara materiil.

Dalam terminologi Islam para ulama fiqh tidak membedakan hukum-hukum bayyinat (pembuktian) dalam perkara mu'amalat (kasus-kasus perdata) dengan hukum-hukum bayyinat dalam perkara 'uqubat (kasus-kasus pidana). Kebenaran yang dicari semuanya adalah kebenaran yang sebenarnya (al haq) atau kebenaran materiil.

Sebagaimana disampaikan Wiryono Projodikoro dalam bukunya Hukum Acara Perdata di indonesia, 
mengatakan bahwa agar tidak ada salah paham, sebaiknya dibuang saja jauh-jauh pengertian kebenaran resmi (kebenaran formal) ini. Sebaiknya tidak hanya dalam acara perkara pidana, melainkan juga dalam acara perdata ditetapkan sebagai dasar, bahwa hakim harus berpedoman pada satu macam kebenaran, yaitu kebenaran seberapa boleh sekedar dapat dikejar sebagai kebenaran sejati (kebenaran materiil). Untuk mencapai kebenaran ini, hakim tidak boleh bersikap lijdelijke (menunggu dan menyerah), melainkan leluasa penuh untuk meminta keterangan-keterangan kepada para pihak yang berperkara tentang apa saja yang dianggap perlu untuk menjatuhkan putusan yang tepat.

Dalam perkembangan hukum sekarang ini, sebaiknya dan lebih adil apabila dalam hukum acara perdata tidak mencari kebenaran formal tetapi mencari kebenaran materiil. Hal ini sebagaimana yang dijelaskan oleh Purwata S. Gandasubrata yang dikutip oleh Raihan A. Rasyid dalam bukunya Hukum Acara Pengadilan Agama, bahwa mengutamakan kebenaran formal tidaklah berarti hukum acara perdata sekarang ini mengenyampingkan kebenaran materil, sebab menurut pendapat para ahli hukum dan yurisprudensi Mahkamah Agung dalam perkara Nomor 3136 K/Pdt/1983 tertanggal 6 Maret 1985, kini sudah tidak pada tempatnya lagi untuk berpendapat demikian. Hukum acara perdata kini sudah harus mencari kebenaran materiil seperti prinsip hukum acara pidana.

Pendapat di atas diperkuat lagi oleh M.Yahya Harahap dalam bukunya Hukum Acara Perdata, yang mengatakan bahwa pada dasarnya peradilan perdata tidak dilarang mencari dan menemukan kebenaran materil. Akan tetapi apabila kebenaran materiil tidak ditemukan, hakim dibenarkan mengambil putusan berdasarkan kebenaran formal.

Dalam pemeriksaan perkara perdata tidak ada garis batas yang tegas antara mencari kebenaran formal dan kebenaran materiil. Bagi hakim yang penting dalam membuat suatu putusan harus dengan alasan dan pertimbangan yang cukup dengan 
didasarkan pada keterangan dan fakta-fakta yang terungkap di persidangan, sehingga putusan tersebut dapat memenuhi rasa keadilan.

Pengadilan agama memiliki wewenang untuk menyelesaikan masalah-masalah yang berkaitan dengan perkawinan, kewarisan, perwakafan dan ekonomi syari'ah. Keempat kewenangan tersebut selalu terkait erat dengan kemaslahatan yang berhubungan dengan kebutuhan pokok umat manusia di dunia dan di akhirat, lahir dan batin, dalam arti tanpa kehadirannya (eksistensi maslahat ini) akan menimbulkan kerusakan di dunia dan di akhirat. Apabila tujuan itu tidak tercapai, maka akan menimbulkan ketidakstabilan kemaslahatan hidup manusia di dunia dan di akhirat, lahir dan batin, bahkan merusak kehidupan itu sendiri. Tujuan hukum Islam yang primer ini hanya bisa dicapai apabila terpeliharannya lima tujuan hukum Islam yang disebut al-dlaruriyat alkhams atau al-kulliyat al-khams, atau sering juga disebut maqasid alsyari'ah, yaitu lima tujuan utama hukum Islam, yaitu memelihara agama, memelihara jiwa, memelihara akal, memelihara keturunan dan/atau kehormatan dan memelihara harta.

Demi melindungi kepentingan yang dlaruri/yang sangat urgen bagi kehidupan manusia, maka tidak selayaknya dalam pembuktian perkara di pengadilan agama yang berkaitan dengan hal tersebut hanya dibuktikan dengan kebenaran formal belaka. Untuk itu maka selayaknya apabila dalam pembuktian perkara di pengadilan agama dengan menggunakan kebenaran materiil. Akan tetapi bila hal demikian sangat sulit dilakukan mengingat keterbatasan hakim dalam pemeriksaanya, maka hakim dapat memutus perkara perdata berdasarkan kebenaran formil.

Dari uraian di atas dapat difahami, bahwa Pengadilan Agama mempunyai ciri dan karakter yang berbeda dengan pengadilan dalam lingkungan Peradilan lainnya, maka dalam pembuktian lebih mengutamakan pencarian kebenaran materiil daripada kebenaran formal. Hal ini karena:

1. Ciri dan karakter pengadilan agama yang berbeda dengan 
pengadilan dalam lingkungan peradilan umum, yakni berbeda dari segi subyek hukum dan obyek hukumnya.

2. Perkara-perkara yang menjadi kewenangan pengadilan agama adalah perkara-perkara yang berkaitan langsung dengan kebutuhan dlaruriyah (kebutuhan primer) manusia.

\section{C.SIMPULAN}

Berdasarkan hasil penelitian dan pembahasan di atas, diperoleh simpulan bahwa Pengadilan Agama mempunyai ciri dan karakter yang berbeda dengan pengadilan dalam lingkungan Peradilan lainnya, maka dalam pembuktian lebih mengutamakan pencarian kebenaran materiil daripada kebenaran formal.

\section{SARAN}

Dalam mengadili perkara, hakim selayaknya tidak mempunyai pemahaman yang dikotomis terhadap kebenaran yang ingin dicapai, apakah itu kebenaran formal ataupun kebenaran materiil, karena sesungguhnya yang dicari hakim adalah kebenaran yang sebenarnya dari perkara yang diselesaikannya.

\section{DAFTAR PUSTAKA}

Al-Shanany, Muhammad bin Ismail al-Kahlani, Subul as Salâm, Dahlan, Bandung, tt.

Departemen Agama RI, Al-Qur'an dan Terjemahnya, Mahkota, Surabaya, 1992.

Harahap, M. Yahya, Beberapa Tinjauan Mengenai Sistem Peradilan dan Penyelesaian sengketa, Citra Adiya Bakti, Bandung, 1997.

Mahkamah Agung RI, Rangkuman Yurisprudensi Mahkamah Agung Indonesia II, Hukum Perdata dan Acara Perdata, Jakarta, 1977.

Mertokusumo, Sudikno, Bunga Rampai Ilmu Hukum, Liberty, Yogyakarta, 1984.

Retnowulan Sutantio dan Iskandar Oeripkartawinata, Hukum Acara Perdata dalam Teori dan Praktek, Mandar Maju, Bandung, 1991.

Riduan Syahrani, Hukum Acara Perdata di Lingkungan Peradilan Umum, Pustaka Kartini, Jakarta, 1988.

Rusyd, Ibn, Bidayah al-Mujtahid wa Nihayah al-Muqtasid, Dar alFikr, Beirut, 1990. 
Tamat Zaifudin, Kebenaran Formal Dalam Pembuktian Di Pengadilan Agama

Soepomo, 1993, Hukum Acara

Perdata Pengadilan Negeri,

Pradnya Paramita, Jakarta, 1993.

Subekti, Hukum Acara Perdata, BPHN Departemen Kehakiman, Bina Cipta, Jakarta, 1989. 